\title{
An Empirical Study on Evaluation of Synergetic Innovation of High - Tech Industry in Shaanxi Province
}

\author{
Du Yueping ${ }^{1}$, Ren Yating ${ }^{2}$ \\ Xidian University, Economy and Management School
}

\begin{abstract}
At present, China's high - tech industry innovation model tends to collaborative innovation. Collaborative innovation can effectively promote the coordinated development of industry and it has become the main trend of future industrial innovation. This paper discusses the connotation and characteristics of collaborative innovation of high-tech industry, and introduces the structure of synergetic innovation of high-tech industry. Constructing the index system of synergetic innovation evaluation of high-tech industry by importing the coordination degree model of composite system. Based on large and medium-sized enterprises in Shaanxi high-tech industry, by the 2007-2014 data processing, analyzing high and new technology industry innovation synergy degree of shaanxi province. Through the empirical research, we find that the synergetic innovation degree of the high-tech industry in Shaanxi province is not high. Combining with the result of the analysis, the countermeasures are put forward to promote the coordinated development of the high-tech industry in Shaanxi province.
\end{abstract}

Keywords: Shaanxi province; high - tech industry; collaborative innovation

\section{Introduction}

Since the 21 st century, with the knowledge-intensive and technology-intensive high-tech industries has promoted the development of the national economy and has provided a major power. "Twelfth Five-Year Plan" proposed to actively "promote high-tech industry bigger and stronger." The 18th National Congress of the Communist Party of China (CPC) also mentioned that scientific and technological innovation is the strategic support for improving social productivity and comprehensive national strength, and sticking to the road of independent innovation with Chinese characteristics. Especially must pay attention to the development of collaborative innovation.Collaborative innovation research within the system evolution process, ordinal variables and subsystems within the overall system could coordinately and orderly development, and thus play a synergistic effect of the whole system. Collaborative innovation has gradually become the future development trend of industrial innovation. High-tech industry play a role of the strategic leader, therefore in the process of development we should attach great importance to the coordinated and orderly development of the elements within the whole system, so as to achieve the coordinated development of industry and enhance the competitiveness of the industry.

At present, the rapid development of high-tech industries in Shaanxi Province, continue to promote the transformation and upgrading of industrial structure, but also improve the quality and efficiency of economic development. In 2014, Xi'an's high-tech industry added value of 76.632 billion yuan, an increase of $27.7 \%$, accounting for $14.0 \%$ of GDP, an increase of $1.7 \%$. Although the development of high-tech industry in Shaanxi Province is rapid, it has a gap with the national average level, the resources are not allocated rationally, the scientific and technological achievements are difficult to be commercialized and the input-output efficiency is poor. Therefore, this paper evaluates the synergetic innovation degree of high-tech industry in Shaanxi Province and puts forward corresponding countermeasures and suggestions, which is of great significance to the further development of high-tech industry in Shaanxi Province.

\section{Literature Survey}

In 1965, Ansoff in his book "Corporate Strategy" for the first time proposed the concept of synergy, that is a synergistic effect of the system, and synergies applied to the operation of enterprises. Synergistic theory was first developed by the famous German physicist Harken in the process of laser evolution. In 1971, Harken proposed a complete system synergetic view. Synergy is the coordination and synchronization of many sub-systems in the system. And finally to form a unified whole process, to " $1+1>2$ " or "2 $+2>5 "$ the overall effect, which is called the synergistic effect. Corning (1998) argues that synergy is "a joint effect of two or more subsystems, elements, or people in a natural or social system through interdependence." With the deepening of the process of world integration, cross-disciplinary, cross-sectoral and transnational scientific and technological activities, the resulting collaborative innovation. Chesbrough (2003) argues that under open innovation, the key to the enterprises' competitive advantage in the future is to utilize external innovative resources to realize the commercial value. The enterprises also pay attention to the coordinated development of internal and external innovation systems. Pekkarinen and Harmaakorpi (2006) argue that the enterprise collaborative innovation network is mainly composed of enterprises, universities, research institutions and intermediary organizations. Tidd (2006), through the collaboration between technological 


\section{International Journal of Science and Research (IJSR) \\ ISSN (Online): 2319-7064}

Index Copernicus Value (2015): 78.96 | Impact Factor (2015): 6.391

innovation and institutional innovation, studied the synergetic innovation of micro-level enterprises. The key to successful enterprise innovation is the synergy between technical factors and non-technical factors. If it can not be well coordinated, Will affect the efficiency of enterprise innovation and performance. Carliss and Eric (2009) redefine the meaning of technical innovation synergies on the basis of adding the cost of design and communication, and put forward the open collaborative innovation model creatively, and systematically and openly construct the collaborative innovation model mechanism.

Xu Qingrui and XieZhangshu (2004) proposed three models of synergetic innovation: technological innovation-oriented, institutional innovation-oriented, technological innovation and institutional innovation, and constructed an innovation evolution model. A case study of zte has carried on the empirical analysis. Huang Lucheng, Zhang Hongcai et al. (2006), the collaborative innovation system is divided into subsystems of economy, science and technology, and studied the collaborative innovation degree of electronics and communications equipment manufacturing, the results found that China's various regions of electronic and communication equipment manufacturing industry has the obvious gap between the degree of order, the overall level is not high.Peng Pai, Cai Li (2007) from the perspective of synergetics, researching the main factors that affecting high-tech industrial cluster. Zhang Shulian, $\mathrm{Hu}$ Dan et al. (2011) divided collaborative innovation system into industrial innovation subsystem and environment subsystem, and the high technology industry of beijing-tianjin-hebei three degree of collaborative innovation is studied, the results show that there is a strong difference among three high technology industry 's collaborative innovation degree. Xiong Li, Sun Youxia et al. (2011) summarized and analyzed the domestic and international research results on collaborative innovation, pointed out the shortcomings of the research, and proposed the future research direction. Gu Jing and XueWeixian (2012) divided the collaborative innovation system into the innovation sub-system and external innovation environment subsystem, evaluated and analyzed the degree of collaborative innovation of the hi-tech industry in China. The results show that the innovation system overall coordination degree is low, the degree of synergy innovation needs to be improved. Liu Yingji (2015) studied the synergetic relationship between technological innovation, institutional innovation and industrial high-end development in China's high-tech industry, and constructed the synergetic model of the composite system. He did empirical analysis towards the three subsystems that is Subsystems of high technology industry technology innovation, system innovation and industry high-end system.

It can be seen from the above studies that scholars have studied the degree of system synergy between industry, enterprises and regions. However, little research has been done on collaborative innovation for a specific province. On a certain province high and new technology industry innovation system coordination degree and the ordering degree of the subsystem, as well as how does the ordering degree of the subsystem affect the synergy of the innovation system? Analyzing and finding out the key factors which restrict the development of the innovation system, the existing research is lacking. Therefore, this paper establishes the collaborative innovation evaluation index system, and uses the synergetic degree model of the composite system to analyze and evaluate the collaborative process of the high-tech industry innovation system of Shaanxi Province. Depth analysis of the impact of the coordination of various subsystems on the whole innovation system of high-tech industry in Shaanxi Province, so as to put forward specific policy recommendations to promote the coordinated and orderly development of the high-tech industry innovation system in Shaanxi Province.

\section{High and New Technology Industry Collaborative Innovation Theory System}

\subsection{The Connotation of Cooperative Innovation System}

The development of high-tech industries present a network chain structure. The connotation of collaborative innovation lies in the process of integrating the innovative elements in the industry to make the innovation resources in the system flow freely and thus achieve the process of superimposing the non-linear innovation utility of the system. Collaborative innovation with the core of knowledge value-added creates value through the cooperation of various innovation bodies (enterprises, universities, research institutes, government and education departments). Industry-university-institute cooperation method is based on collaborative innovation. Cooperative innovation is the latest development of the theory of national innovation system. It is an important innovation mode in national innovation system. The efficiency and the operation mode of knowledge value-added greatly determine the performance of cooperation. The transmission of innovative resources presents a network. Innovative resources through the value chain, supply chain and logistics and other carriers from different directions in the input-output and competitive cooperation delivering innovation impact, and has a chain reaction. In the specific high-tech industry economic environment, collaborative innovation will play its respective advantages by enterprises, governments, universities, scientific research institutions, intermediary service agencies, suppliers and users, through the integration of complementary resources to realize complementary advantages, accelerate the commercialization and promote the industrialization of technological achievements. All parties work together to promote industrial technology innovation and industrialization of scientific and technological achievements.

\subsection{The Characteristics of Cooperative Innovation System}

On the basis of Haken's coordination theory, high-tech industry collaborative innovation system has the self-organizing mechanism, so the innovation system has the characteristics of openness, fluctuation and nonlinearity. 


\section{International Journal of Science and Research (IJSR) \\ ISSN (Online): 2319-7064}

Index Copernicus Value (2015): 78.96 | Impact Factor (2015): 6.391

First of all, openness is the premise of building collaborative innovation system. The innovation system of high-tech industry can only exchange material, information and energy with external environment only if it meets the prerequisite of opening. The innovation subject and the external innovation environment communicate with each other through information, talent, technology and capital. Through the communication, the deficiencies and shortcomings of the system are found to maintain the balance of the innovation system status and provide power and pressure for innovation activities. Secondly, the fluctuation is the inducement of the self-organization evolution of the innovation system, which causes the system to evolve from disorder to order. In the process of industrial innovation, the evolution of control variables makes the system to equilibrium, and the random fluctuations in the system will be enlarged immediately by related synergistic effect, leading to a huge fluctuation, and then push the system into a new stable state. The factors that cause the ups and downs of the innovation activities of high-tech industry innovation come from the internal or external innovation environment. Finally, nonlinearity is the basic dynamic mechanism for the evolution of collaborative innovation system. The non-linear effect of the system makes each factor within the system mutually cause and effect. The competition and coordination among the elements promote the system from disorder to orderly development. The non-linearity is embodied in the market realization of product or process innovation caused by the interaction, feedback and synergy among the elements in the industry innovation body.

\subsection{The Elements and Structures of Cooperative Innovation}

High-tech industry innovation system is an interactive process, composed of a variety of subjects, involving a variety of reasons. Enterprises need to interact with users, competitors, research institutions, authorities, etc., to mobilize and allocate resources (capital, technology, knowledge, talent, etc.) through parallel and vertical linkages. High-tech industry collaborative innovation system from the structure can be divided into collaborative innovation main body and external innovation environment. The collaborative innovation body and the external innovation environment are two subsystems which restrict each other, interdependence and interact with each other. The concrete cooperative structure is shown in Figure 1.

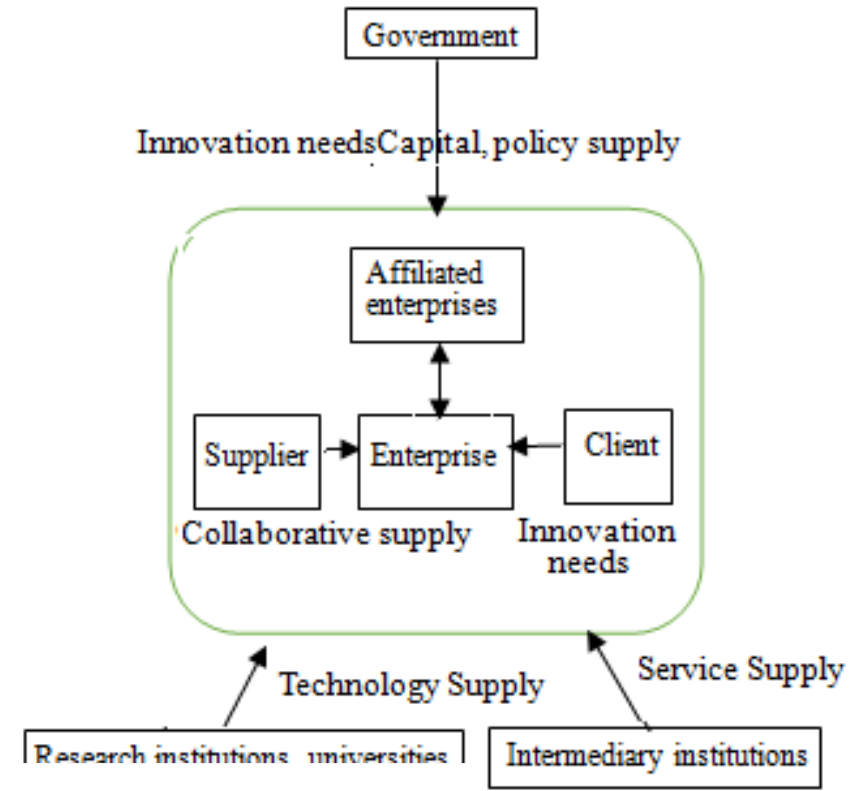

Figure 1: High-tech industry collaborative innovation structure

Enterprises are the core of the industry collaborative innovation system, and also the demand side of innovation, and the interactive activities with related enterprises, suppliers and customers constitute the main body of innovation. The efficiency of the innovation subject is decided by the innovation of the enterprise. As the representatives of the market environment, the related enterprises, suppliers and customers make demands and provide the innovation direction for the enterprise innovation.

Government, universities, research institutions and intermediaries constitute the external innovation environment. Universities and research institutions are the supply side of technological innovation, providing the technology and knowledge for innovation main body. Government as an external regulator, not only provide innovative financial input for innovation main body, but also put forward the industrial innovation demand through policy planning and other means. Intermediary agencies as a catalyst for innovation activities. Intermediaries include industry associations, research and development service center, consultancy, etc. Intermediary institutions build a platform for collaborative innovation, provide services for innovation activities, and put forward innovation needs. Intermediary institutions promote industrial innovation.

High and new technology industry collaborative innovation system is an open dynamic system. The degree of coordination among the elements in the system will affect the system innovation performance. Therefore, the system through constant feedback to adjust, through dynamic, interactive adaptive learning to adjust the structure, so as to achieve higher efficiency of innovation. 


\section{International Journal of Science and Research (IJSR) \\ ISSN (Online): 2319-7064}

Index Copernicus Value (2015): 78.96 | Impact Factor (2015): 6.391

\section{High and New Technology Industry Innovation Synergy Degree Evaluation in Shaanxi Province}

According to the theory of synergetics, the key to the system from disorder to order is the coordination between the order parameters of the system. Therefore, the author introduces the synergetic degree model of the composite system established by MengQingsong and Han Wenxiu, and makes an empirical study on the synergetic degree of the industrial innovation main body and the external environment of the collaborative innovation in the high-tech industry collaborative innovation system of Shaanxi Province. In this paper, the main innovation is divided into innovative resources and innovative performance, Therefore, Shaanxi Province high-tech industry collaborative innovation system can be divided into: innovation resource subsystem, innovation performance subsystem and innovation environment subsystem.

\subsection{Evaluation Model of Synergetic Degree}

Set new and high technology industries in collaborative innovation system includes subsystems for $\mathrm{Sj}, \mathrm{j} \in[1,2,3]$, $\mathrm{S} 1$ represents the innovation resource subsystem, S2 represents the innovation performance subsystem and S3 represents the innovation environment subsystem. Subsystem contains the order parameter variables which are denoted by ej=(ej1,ej2,..ejm), $m \geq 1, \beta j i \leq e j i \leq \alpha j i, i[1, m]$. The order parameter variables included in the subsystem are the indicators to describe the innovation mechanism and operation of the collaborative innovation system of the high-tech industry. When the indicators are positive indicators, the higher the value of ej1, ej2, .., ejm, the higher the order of innovation system, the smaller the value, the lower the order of innovation system; when the index is negative, The smaller the value, the higher the degree of order of the system, the greater the value, the lower the degree of order. Therefore, the following formula is defined as the ordered degree of system order parameter.

$$
\left\{\begin{array}{c}
\mathrm{j}(\text { eji })=(\text { eji- } \beta \mathrm{ji}) /(\alpha \mathrm{ji}-\beta \mathrm{ji}) \text {, eji is a positive indicator }(1) \\
(\alpha \mathrm{ji}-\mathrm{eji}) /(\alpha \mathrm{ji}-\beta \mathrm{ji}), \text { eji is a negative indicator }
\end{array}\right.
$$

Where $\beta \mathrm{ji}$ and $\alpha \mathrm{ji}$ are the upper and lower limits of the order parameter variable ej, respectively.

The formula (1) shows thatj(eji) $\in[0,1]$, and the greater ofj(eji), the larger the "contribution" fromj(eji) to the system degree of order; In contrast, the smaller ofj(eji), the smaller the "contribution" fromj(eji) to the system degree of order. The influence of the order parameter ej on the order degree of the system $\mathrm{Sj}$ can be expressed by the integration of uj (eji). In this paper, the linear weighted summation method is used.

$$
\mathrm{j}(\mathrm{ej})=, \quad \lambda \mathrm{i} \geq 0, \quad=1 . \quad(2)
$$

The overall coordination degree of the composite system should consider the order degree of all the subsystems. The improvement of order degree of a single subsystem can not make the whole system coordinate, if only the order degree of all the subsystems is improved, the whole system can coordinate better. Set the initial time t0, the order of the degree of each subsystem is $, j=1,2,3$. When the entire complex system to the development of time $t 1$, at this time the order of the degree of each subsystem is $, j=1,2,3$. Delimiting $\mathrm{cm}$ is the complex system coordination degree.

$\mathrm{cm}=\theta \quad$ (3)

In the formula, $\theta=\min _{j}\left[\mu \mathrm{j}^{1}(e j)-\mu \mathrm{j}^{0}(e j) \neq 0\right] / \mid \min _{j}\left[\mu \mathrm{j}^{1}(e j)-\right.$ $\left.\mu \mathrm{j}^{0}(e j) \neq 0\right] \mid, \mathrm{j}=1,2,3$

The value of $\theta$ is 1 and -1 , and the complex system has a positive degree of coordination only if any $\mathrm{j}$ satisfies $>$; Otherwise, $\theta=-1 . \mathrm{Cm} \in[-1,1]$, the greater the value, the greater the degree of coordination of the overall system, on the contrary the lower. Formula (3) combining the situation of all subsystems. When the order degree of one subsystem is improved to a great extent, while the order degree of other subsystems improve less or decrease, then the coordination degree of the whole system is not high or Is not harmonious, reflect as $\mathrm{cm} \in[-1,0]$.

\subsection{Evaluation System}

Based on the principles of scientificity, objectivity, systematization, availability, rationality and operability, this paper constructs an index system which can reflect the basic attributes of subsystems. As shown in the following table.

Table 1: The new and high technology industries synergy

\begin{tabular}{|c|c|c|}
\hline \begin{tabular}{|l|} 
Target layer \\
\end{tabular} & Subsystems & Order variable \\
\hline \multirow{17}{*}{\begin{tabular}{|} 
High and \\
new \\
technology \\
industry \\
collaborative \\
innovation \\
degree
\end{tabular}} & \multirow{10}{*}{$\begin{array}{l}\text { innovation } \\
\text { resource } \\
\text { subsystem } \\
\text { (S1) }\end{array}$} & R\&D staff full-time equivalent \\
\hline & & (person / year) (e11) \\
\hline & & R\&D expenses Internal expenditure \\
\hline & & (10 thousand yuan) (e12) \\
\hline & & $\begin{array}{l}\text { Expenditure on technological } \\
\text { transformation }\end{array}$ \\
\hline & & (10 thousand yuan) (e13) \\
\hline & & $\begin{array}{l}\text { Expenditure on digestion and } \\
\text { absorption }\end{array}$ \\
\hline & & (10 thousand yuan) (e14) \\
\hline & & $\begin{array}{c}\text { Expenditure on new product } \\
\text { development (10thousand yuan) (e15) }\end{array}$ \\
\hline & & $\begin{array}{c}\text { New fixed assets (100 million yuan) } \\
(\mathrm{e} 16)\end{array}$ \\
\hline & \multirow{3}{*}{$\begin{array}{l}\text { innovation } \\
\text { performance } \\
\text { subsystem } \\
\text { (S2) }\end{array}$} & $\begin{array}{l}\text { Number of patent applications } \\
\text { (pieces) (e21) }\end{array}$ \\
\hline & & $\begin{array}{l}\text { Number of valid invention patents } \\
\text { (pieces) (e22) }\end{array}$ \\
\hline & & $\begin{array}{l}\text { Sales revenue of new products } \\
(10 \text { thousand yuan })(\mathrm{e} 23)\end{array}$ \\
\hline & \multirow{4}{*}{$\begin{array}{l}\text { innovation } \\
\text { environment } \\
\text { subsystem } \\
\text { (S3) }\end{array}$} & \begin{tabular}{|c|} 
Number of regional R\&D institutions \\
(unit) (e31)
\end{tabular} \\
\hline & & $\begin{array}{l}\text { The proportion of R\&D expenditure } \\
\text { in the region to GDP }(\mathrm{e} 32)\end{array}$ \\
\hline & & $\begin{array}{c}\begin{array}{c}\text { The proportion of local S\&T funding } \\
\text { to total fiscal expenditure (e33) }\end{array} \\
\end{array}$ \\
\hline & & $\begin{array}{l}\text { Number of contracts in the regional } \\
\text { technology market }(10,000)(\mathrm{e} 34)\end{array}$ \\
\hline
\end{tabular}
innovation evaluation index 


\section{International Journal of Science and Research (IJSR) \\ ISSN (Online): 2319-7064 \\ Index Copernicus Value (2015): 78.96 | Impact Factor (2015): 6.391}

The innovation resource subsystem embodies the resource input of the innovation process. The full-time equivalent of R\&D personnel reflects the amount of talent input in the innovation process. $\mathrm{R} \& \mathrm{D}$ expenditure internal expenditure reflects the innovation process of financial investment. Expenditure on technological transformation and expenditure on digestion and absorption reflect the funds invested by enterprises in technology transfer. New product development expenditure represents the input of product innovation. The new fixed assets embodies the material input in the innovation process.

The innovation performance subsystem determines the specific performance of innovation activities. New product sales revenue and effective invention patents reflect the output capacity of the innovation system. The number of patent applications reflects the $R \& D$ results of industrial innovation activities.

Innovation environment subsystem refers to government authorities, universities, research institutions and agencies constructed external operating environment for the technological innovation and technology transfers of high-tech industries. The number of regional R\&D institutions represents the technical supply to the innovation process by research institutions. The share of $R \& D$ expenditure in regional GDP and the share of local S\&T expenditure in total fiscal expenditure reflects the government's support for industrial technological innovation. The number of regional technology market contracts represents the degree of activity in the regional technology market and also reflects the efficiency of technology transfer.

\subsection{Data source and processing}

This paper collects the data of China High-tech Industry Statistical Yearbook and China Statistical Yearbook of Science and Technology from 2007 to 2014. As shown below.

Table 2: The original data for Subsystem S1

\begin{tabular}{|c|c|c|c|c|c|c|}
\hline years & $\begin{array}{c}\text { R\&D staff } \\
\text { full-time } \\
\text { equivalent } \\
\text { (person/year) } \\
\text { (e11) }\end{array}$ & $\begin{array}{c}\text { R\&D expenses } \\
\text { Internal } \\
\text { expenditure } \\
(10 \text { thousand } \\
\text { yuan) }(\mathrm{e} 12)\end{array}$ & $\begin{array}{c}\text { Expenditure on } \\
\text { technological } \\
\text { transformation } \\
(10 \text { thousand } \\
\text { yuan) }(\mathrm{e} 13)\end{array}$ & $\begin{array}{c}\text { Expenditure on } \\
\text { digestion and } \\
\text { absorption } \\
(10 \text { thousand } \\
\text { yuan) (e14) }\end{array}$ & $\begin{array}{c}\text { Expenditure on } \\
\text { new product } \\
\text { development } \\
\text { (10thousand } \\
\text { yuan) (e15) }\end{array}$ & $\begin{array}{c}\text { New fixed } \\
\text { assets (100 } \\
\text { million yuan) } \\
\text { (e16) }\end{array}$ \\
\hline 2007 & 13324 & 160777 & 165459 & 529 & 161364 & 38.9 \\
\hline 2008 & 10046 & 169291 & 88442 & 529 & 159995 & 50.6 \\
\hline 2009 & 10594 & 214485 & 143023 & 868 & 244160 & 78.2 \\
\hline 2010 & 12006 & 261870 & 156236 & 3711 & 326309 & 286.43 \\
\hline 2011 & 13039 & 450657 & 108964 & 2632 & 446259 & 85.11 \\
\hline 2012 & 15624 & 506251 & 128228 & 585 & 514357 & 127.19 \\
\hline 2013 & 19221 & 527461 & 123583 & 149 & 608083 & 147.97 \\
\hline 2014 & 22371 & 617530 & 265960 & 244 & 713276 & 205.78 \\
\hline
\end{tabular}

Table 3: The original data for Subsystem S2

\begin{tabular}{|c|c|c|c|}
\hline years & $\begin{array}{c}\text { Number of patent } \\
\text { applications (pieces) (e21) }\end{array}$ & $\begin{array}{c}\text { Number of valid invention } \\
\text { patents (pieces) (e22) }\end{array}$ & $\begin{array}{c}\text { Sales revenue of new products } \\
\text { (10thousand yuan) (e23) }\end{array}$ \\
\hline 2007 & 528 & 212 & 1550759 \\
\hline 2008 & 473 & 337 & 1654468 \\
\hline 2009 & 569 & 536 & 1072488 \\
\hline 2010 & 732 & 466 & 1586068 \\
\hline 2011 & 964 & 828 & 1997131 \\
\hline 2012 & 1252 & 1089 & 2071035 \\
\hline 2013 & 1867 & 1503 & 1975150 \\
\hline 2014 & 1576 & 1847 & 2748567 \\
\hline
\end{tabular}




\section{International Journal of Science and Research (IJSR) \\ ISSN (Online): 2319-7064}

Index Copernicus Value (2015): 78.96 | Impact Factor (2015): 6.391

Table 4: The original data for Subsystem S3

\begin{tabular}{|c|c|c|c|c|}
\hline years & $\begin{array}{c}\text { Number of regional } \\
\text { R\&D institutions } \\
\text { (unit) (e31) }\end{array}$ & $\begin{array}{c}\text { The proportion of R\&D } \\
\text { expenditure in the region } \\
\text { to GDP (e32) }\end{array}$ & $\begin{array}{c}\text { The proportion of local } \\
\text { S\&T funding to total } \\
\text { fiscal expenditure (e33) }\end{array}$ & $\begin{array}{c}\text { Number of contracts in } \\
\text { the regional technology } \\
\text { market (10,000) (e34) }\end{array}$ \\
\hline 2007 & 94 & 2.11 & 1.72 & 21 \\
\hline 2008 & 109 & 1.96 & 1.68 & 22.6 \\
\hline 2009 & 115 & 2.32 & 1.72 & 21.4 \\
\hline 2010 & 96 & 2.15 & 1.77 & 23.6 \\
\hline 2011 & 90 & 1.99 & 1.73 & 28.2 \\
\hline 2012 & 121 & 1.99 & 1.78 & 29.5 \\
\hline 2013 & 103 & 2.12 & 1.94 & 29.7 \\
\hline 2014 & 109 & 2.07 & 1.9 & \\
\hline
\end{tabular}

In view of the difference between the units of the indicators, the original data are standardized before the empirical analysis. The standardized data is substituted into the formula (1), the order degree of the order variables of each subsystem can be calculated. As shown below.

Table 5: Order degree of order variables in $\mathrm{S} 1$

\begin{tabular}{|c|c|c|c|c|c|c|}
\hline years & $1(\mathrm{e} 11)$ & $1(\mathrm{e} 12)$ & $1(\mathrm{e} 13)$ & $1(\mathrm{e} 14)$ & $1(\mathrm{e} 15)$ & $1(\mathrm{e} 16)$ \\
\hline 2007 & 0.266 & 0.000 & 0.434 & 0.107 & 0.002 & 0.000 \\
\hline 2008 & 0.000 & 0.019 & 0.000 & 0.107 & 0.000 & 0.047 \\
\hline 2009 & 0.044 & 0.118 & 0.307 & 0.202 & 0.152 & 0.159 \\
\hline 2010 & 0.159 & 0.221 & 0.495 & 1.000 & 0.301 & 1.000 \\
\hline 2011 & 0.243 & 0.635 & 0.116 & 0.697 & 0.517 & 0.187 \\
\hline 2012 & 0.453 & 0.756 & 0.224 & 0.122 & 0.640 & 0.357 \\
\hline 2013 & 0.744 & 0.803 & 0.198 & 0.000 & 0.810 & 0.441 \\
\hline 2014 & 1.000 & 1.000 & 1.000 & 0.027 & 1.000 & 0.674 \\
\hline
\end{tabular}

Table 6: Order degree of order variables in S2

\begin{tabular}{|c|c|c|c|}
\hline years & $2(\mathrm{e} 21)$ & $2(\mathrm{e} 22)$ & $2(\mathrm{e} 23)$ \\
\hline 2007 & 0.039 & 0.000 & 0.285 \\
\hline 2008 & 0.000 & 0.076 & 0.347 \\
\hline 2009 & 0.069 & 0.198 & 0.000 \\
\hline 2010 & 0.186 & 0.155 & 0.306 \\
\hline 2011 & 0.352 & 0.377 & 0.552 \\
\hline 2012 & 0.559 & 0.536 & 0.596 \\
\hline 2013 & 1.000 & 0.790 & 0.539 \\
\hline 2014 & 0.791 & 1.000 & 1.000 \\
\hline
\end{tabular}

Table 7: Order degree of order variables in $\mathrm{S} 3$

\begin{tabular}{|c|c|c|c|c|}
\hline years & $3(\mathrm{e} 31)$ & $3(\mathrm{e} 32)$ & $3(\mathrm{e} 33)$ & $3(\mathrm{e} 34)$ \\
\hline 2007 & 0.129 & 0.417 & 0.154 & 0.000 \\
\hline 2008 & 0.613 & 0.000 & 0.000 & 0.184 \\
\hline 2009 & 0.806 & 1.000 & 0.154 & 0.046 \\
\hline 2010 & 0.194 & 0.528 & 0.346 & 0.230 \\
\hline 2011 & 0.000 & 0.083 & 0.192 & 0.529 \\
\hline 2012 & 1.000 & 0.083 & 0.385 & 0.828 \\
\hline 2013 & 0.419 & 0.444 & 1.000 & 0.977 \\
\hline 2014 & 0.613 & 0.306 & 0.846 & 1.000 \\
\hline
\end{tabular}

\subsection{The index weights of correlation matrix method}

The correlation coefficient between indexes reflects the degree of mutual influence between indicators, the greater the absolute value of the correlation coefficient, the higher the degree of impact between indicators; On the contrary, the mutual influence on each other the lower. If a certain indicator in the index system has a high degree of correlation with all other indicators, the indicator will have a greater impact on other indicators, the role of the index system is larger, so the weight should be larger. On the other hand, if a certain indicator in the index system has a low degree of correlation with all other indicators, its role in the index system is also smaller, the weight should be small. Therefore, the steps of the correlation matrix weighting method are expressed as follows.

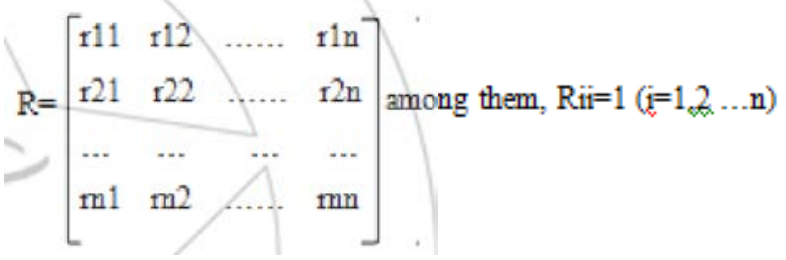

command $\mathrm{Ri}=, \quad(\mathrm{i}=1,2, \ldots, \mathrm{n})$

Ri represents the total impact of the $i$-th index on the other (n-1) indicators. The weights of each index can be obtained by normalizing $\mathrm{Ri}$. Wi=Ri/ $(\mathrm{i}=1,2, \ldots, \mathrm{n})$

In this paper, correlation matrix method can calculate $\mathrm{S} 1, \mathrm{~S} 2$, S3 weights. The results are shown below.

Table 8: The weight of the subsystem S1

\begin{tabular}{|c|c|c|c|c|c|c|}
\hline Order variable & e11 & e12 & e13 & e14 & e15 & e16 \\
\hline Weight & 0.216 & 0.189 & 0.146 & 0.095 & 0.203 & 0.15 \\
\hline
\end{tabular}

Table 9: The weight of the subsystem S2

\begin{tabular}{|c|c|c|c|}
\hline Order variable & e21 & e22 & e23 \\
\hline Weight & 0.335 & 0.353 & 0.312 \\
\hline
\end{tabular}

Table 10: The weight of the subsystem S3

\begin{tabular}{|c|c|c|c|c|}
\hline Order variable & e31 & e32 & e33 & e34 \\
\hline Weight & 0.265 & 0.240 & 0.310 & 0.185 \\
\hline
\end{tabular}

\subsection{Ordered degree of subsystem and system coordination degree}

Finally, the data of Table 5, Table 6, Table 7, Table 8, Table 9, and Table 10 are substituted into the formula (2) to obtain the order of the innovation resource subsystem S1, innovation performance subsystem S2 and innovation environment subsystem S3. The order degree of each

\section{Volume 6 Issue 1, January 2017




\section{International Journal of Science and Research (IJSR) \\ ISSN (Online): 2319-7064 \\ Index Copernicus Value (2015): 78.96 | Impact Factor (2015): 6.391}

subsystem is substituted into formula (3) to calculate the synergy degree of the high-tech industry innovation system in Shaanxi Province. The results are shown in the following table.

\begin{tabular}{|l|l|l|l|l|}
\hline 2011 & 0.389 & 0.423 & 0.177 & -0.069 \\
\hline 2012 & 0.469 & 0.562 & 0.557 & 0.388 \\
\hline 2013 & 0.572 & 0.782 & 0.709 & 0.540 \\
\hline 2014 & 0.858 & 0.930 & 0.683 & 0.670 \\
\hline
\end{tabular}

Table 11: The order degree of the subsystem and the degree of system coordination

\begin{tabular}{|c|c|c|c|c|}
\hline years & $\begin{array}{c}\text { The order } \\
\text { degree of S1 }\end{array}$ & $\begin{array}{c}\text { The order } \\
\text { degree of S2 }\end{array}$ & $\begin{array}{c}\text { The order } \\
\text { degree of S3 }\end{array}$ & $\begin{array}{c}\text { Synergy degree of } \\
\text { compound system }\end{array}$ \\
\hline 2007 & 0.131 & 0.102 & 0.182 & \\
\hline 2008 & 0.021 & 0.135 & 0.196 & -0.038 \\
\hline 2009 & 0.151 & 0.093 & 0.510 & -0.038 \\
\hline 2010 & 0.454 & 0.213 & 0.328 & 0.173 \\
\hline
\end{tabular}

\subsection{Conclusion and analysis}

To facilitate the analysis of high-tech industry in Shaanxi Province collaborative innovation, according to Table 11, we draw Figure 2.

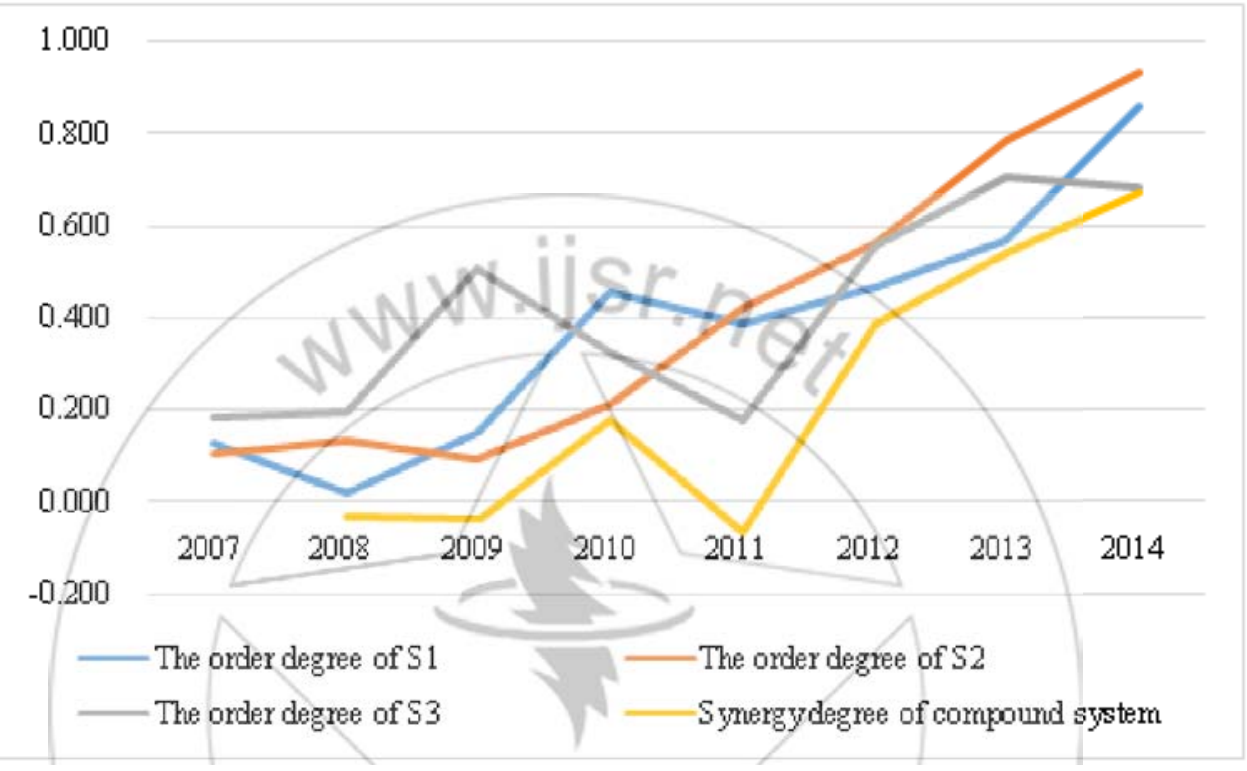

Figure 2: 2007-2014 High - tech industry collaborative innovation degree in Shaanxi Province

The orderly degree of innovation resource subsystem and innovation performance subsystem is on the rise. Through the study of raw data, we find that when Shaanxi Province increases the input of R\&D personnel,research and development spending and new fixed assets such as human, financial and investment, number of patent applications, effective number of invention patents and new products sales also ascend, accordingly the subsystems of innovation resources and innovation performance of ordered degree increase gradually. But the data of the fluctuation range of the innovation resource subsystem are mainly the two items of technological transformation expenditure and digestion and absorption expenditure, which shows that technology transfer, digestion and absorption have a significant impact on the innovation activities of the high-tech industry.

The order degree fluctuation of innovation environment subsystem is obvious. 2009 and 2013, two years of the highest degree of order. Corresponding to the original data, it can be seen that the change of the order degree of the subsystem has a great relationship with the change of the proportion of R \& $\mathrm{D}$ expenditure in the region's GDP. It shows that the construction of external innovation environment is mainly based on government investment, neglecting the environment construction of science and technology market.
The overall synergetic level of Shaanxi high-tech industry collaborative innovation system is not high. 2008, 2009 and 2011, the degree of synergy is negative, indicating that the entire system is clearly uncoordinated. Although the degree of synergy in 2010 has increased, but in 2011 had a significant decline, and gradually increased after 2012. This shows that the high-tech industry in Shaanxi Province collaborative innovation system's development is not stable enough, the system resource allocation is not balanced. At the same time, with the improvement of the coordination degree, the order of innovation resource subsystem and innovation performance subsystem is higher than that of innovation environment subsystem. It shows that the development of the innovation subject is faster than the innovation external environment in recent years and has a great influence on the system. The development of the external environment relies heavily on the investment guidance and support of the government departments, and does not give full play to the market's ability to allocate scientific and technological resources. The lack of technology introduction and technological transformation leads to the decline of innovation activities. Therefore, in the construction of high-tech industry collaborative innovation system, the Government should not only increase investment in science and technology, through various policies to encourage and support high-tech enterprise innovation 


\section{International Journal of Science and Research (IJSR) \\ ISSN (Online): 2319-7064}

Index Copernicus Value (2015): 78.96 | Impact Factor (2015): 6.391

activities, but also speed up the construction of innovation environment, pay close attention to improve the high-tech industry collaborative innovation system. Only in this way can we maintain the benign and stable development of the industry.

\section{Policy Proposals for Synergetic Innovation of High - tech Industry in Shaanxi Province}

Based on the above empirical analysis, combined with the causes of the problem, this paper proposes the following suggestions.

\section{Increase $R \& D$ investment, and to clarify the functions of government}

The result of empirical analysis proves that the input of resources will greatly affect the orderliness of the subsystem. Despite the high-tech industry in Shaanxi Province has increased investment in resources year by year, but the indicators compared with other parts of the country still have a certain gap. Therefore, in terms of capital, companies must ensure that $R \& D$ investment in sales accounted for a certain percentage, there is sufficient funds to support technological innovation; On talents, increase the reward for technology innovation, especially to reward innovation talents, form incentives to him or her, make him or her more enthusiastic on research and development, this will also attract foreign talent to join. At the same time, the government should strengthen the incentive, guidance, standardization and coordination of the innovation external environment, increase the construction of innovative services, and fully mobilize the enthusiasm and creativity of the various entities in the innovation system. The government should intensify market supervision, strengthen market management, improve intellectual property protection law and patent protection system, and strengthen the protection of intellectual property rights. The government should increase the input of public products and strongly support the industrial innovation activities. The government should protect the interests of the main body of the system to ensure the enthusiasm of the main body of innovation, and create a standardized and orderly, vibrant market environment.

\section{Adjust the input structure of innovation resources}

In recent years, the high-tech industry resources in Shaanxi Province focused on the original innovation activities, innovation turn imitation, introduction, digestion and absorption into the original innovation. However, the original innovation capacity of high-tech industry in Shaanxi Province is insufficient, the economic effect is limited, it is difficult to promote the development of industry. So at the present stage shaanxi province high and new technology industry, on the basis of the original innovation ability is insufficient, must strengthen the introduction of digestion, absorption and innovation, attaches great importance to the technological transformation, digestion and absorption of funds investment. Enterprises through imitation of foreign advanced technology, strive for a breakthrough in core technology to form their own intellectual property rights, but also for the development of the industry's original accumulation of accumulated capital.

\section{Build the platform for Production-study-research cooperation}

Enterprises are the demand side of technology, while the demand side's own innovation capability is often inadequate. Universities and research institutions are the providers of technological innovation, but their marketability is weak. Therefore, on the basis of understanding the division of labor among the parties, the government will build bridges to promote the development of industry, academia and research. Such as: identification of research projects and the establishment of science and technology park, research and development centers, experimental base of scientific achievements incubator; Advancing the construction of intermediary agencies such as consulting firms, and accelerating the transmission and diffusion of technological innovation through the services of intermediaries; Raising funds to establish scientific and technological enterprises in colleges and universities to accelerate the commercialization of scientific and technological achievements; Developing the appropriate personnel In the transmission of technology to promote innovation into practical products, and accelerating the digestion and absorption of re-innovation.

\section{Broaden the diversified financing channels}

The more input and a higher risk of high-tech industries, government and enterprise's investment is far from enough. But the high-risk characteristics of high-tech industries make other financing institutions can't easily invest in enterprises. So establish venture capital mechanism, to further broaden the financing channels of high-tech industries. For example: Cultivating strong enterprises to establish venture capital firms; Guide foreign capital and various social funds to participate in technological innovation activities; Cooperating with foreign enterprises or other governments to attract foreign investment, to set up the international funds, etc.

\section{Reference}

[1] Ansoff I. Corporate Strategy[M].New York: McGraw Hill.1965.

[2] Haken H 9ynergetics. 2004. Instruction and Advanced Topics [M]. 3nd.Berlin: Springer, 24-45.

[3] Coming Peter A. The Synergism hypothesis: on the concept of synergy and its role in the evolution of complex systems[J]. Journal of Social and Evolutionary Systems, 1998, 21(2):133-172.

[4] Chesbrough H W 2003. Open Innovation [M].Harvard Business School Press, Boston, MA.

[5] Pekkarinen S, Harmaakorpi V. Building regional innovation networks: The definition of an age business core process in a regional innovation system[J]. Regional Studies, 2006, 40(4): 401-413.

[6] Tidd, The importance of diverse collaborative networks for the novelty of product innovation $[\mathrm{J}]$.Technovation, 2006,27(6-7):367-377.

[7] Carliss B, Eric von H.Modeling a Paradigm Shift:From Producer Innovation to User and Open Collaborative 


\section{International Journal of Science and Research (IJSR) \\ ISSN (Online): 2319-7064}

Index Copernicus Value (2015): 78.96 | Impact Factor (2015): 6.391

Innovation[EB].http://papers.ssrn.com 2009(11).

[8] 许庆瑞, 谢章澎. 企业创新协同及其演化模型研究 [J]. 科学学研究 2004(3):29-33

[9] 黄鲁成, 张红彩等. 我国电子及通信设备制造业的系 统协同度分析 $[\mathrm{J}]$.统计与决策, 2006(6)78-80.

[10]彭看, 蔡莉. 基于协同学理论的高技术产业集群生产 主要影响因素研究[J]. 山东大学学报(哲学社会科学 版), 2007, 1: 72-78.

[11] 张淑莲, 胡丹等. 京津冀高技术产业协同创新研究 [J]. 河北工业大学学报, 2011, 12(40): 107-112.

[12] 熊励, 孙友霞, 蒋定福, 刘文. 协同创新研究综述——基 于实现途径视角 $[\mathrm{J}]$. 科技管理研究,2011,14:15-18.

[13] 顾菁, 薛伟贤. 高技术产业协同创新研究[[J]. 科技进步 与对策，2012, 11(29): 84-89.

[14]刘英基. 高技术产业技术创新、制度创新与产业高端 化协同发展研究——基于复合系统协同度模型的 实证分析 $[J]$ 科技进步与对策，2015, 32(2):66-72.

[15] 郑刚, 梁欣如. 全面协同:创新致胜之道——技术与非 技术要素全面协同机制研究 [J]. 科学学研 究,2006,S1:268-273.

\section{Authors Profile}

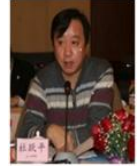

Du Yueping is professor at Xidian University, China

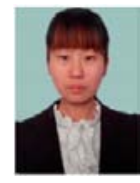

Ren Yating, Educational Background: Bachelor's

degree, Xidian University 